\title{
渦発生体付き流路における圧力損失と伝熱促進* (プラントル数の影響)
}

\author{
加藤 健司 ${ }^{* 1}$, 脇本 辰郎 ${ }^{* 1}$, 西村 貴志 ${ }^{* 2}$

\section{Heat Transfer Enhancement and Pressure Loss in a Channel with a Vortex Generator (Effect of Prandtl Number)}

\author{
Kenji KATOH ${ }^{* 1}$, Tatsuro WAKIMOTO and Takashi NISHIMURA \\ ${ }^{* 1}$ Osaka City Univ. Dept. of Mechanical Engineering \\ Sugimoto, Sumiyoshi-ku, Osaka-shi, 558-0022 Japan
}

The efficiency index $n$, (i.e., the ratio between heat transfer enhancement and drag increase from a smooth channel), is discussed in a channel with a delta wing-type vortex generator (VG) installed on the wall in laminar and turbulent flow. In this report, the effect of Prandtl number $\operatorname{Pr}$ on $\eta$ is mainly discussed by use of the equation obtained in the preceding report to estimate various effects on the heat transfer enhancement. From the results of direct numerical simulation, $\eta$ decreases slightly in the turbulent flow with $P r$, while it increases noticeably in the laminar flow. In the laminar flow, since there is no background turbulence in the smooth channel, the fluctuation generated by VG directly enhances the heat transfer, which is greater at high $P r$ where the thermal diffusion effect is weakened. In addition, the increase of convective heat transfer near the wall has an important effect on the good efficiency. In the turbulent flow, on the other hand, the efficiency index slightly decreases with Pr since the turbulence generated by VG is not strongly dependent on the Prandtl number. The influence of the notched hole beneath the wing is discussed from the numerical results.

Key Words : Heat Transfer Enhancement, Drag Increase, Vortex Generator, Prandtl Number, Numerical Simulation

\section{1. 緒言}

種々の工業装置で用いられる熱交換器において，その伝熱性能を向上させるために様々な手法が提案されてい $ろ^{(1)-(3)}$. 流路壁面に渦発生体, リブや㧖りテープなどの伝熱促進体を設置して, 境界層の再発達や乱れの促進に より対流熱輸送を増加させるのは, 最も代表的な手法の一つである. 最近では, 精密加工された 3 次元構造の粗

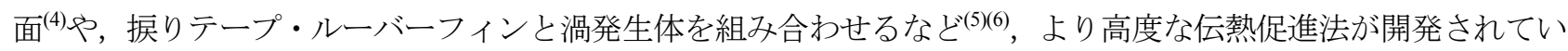
る. ところで, 実際の装置内で伝熱促進体を設置する場合, 様々な条件下で使用する可能性が考えられる. 例え ば, 熱交換器のコンパクト化や高密度化に伴い, 乱流に加えて層流中での伝熱促進や圧力損失について, 実験や 数值計算による検討が多くなされている(7)-(10). 一般に, 層流中ではリブなどの粗さ要素よりも流路の閉塞が小さ いねじりテープやウィングなどの渦発生体が用いられることが多い．滑面流れを基準にして，圧力損失の増加率 に対する伝熱促進率で定義される効率 $\eta(\text { efficiency index })^{(4)}$ に着目寸ると，一般に乱流よりも層流の方が良好で, 層流中に伝熱促進体を設置したとき, $\eta$ が 1 以上となる場合も認められている(10). また, 流体の物性の変化に対 し，伝熱促進体としてワイヤコイルを用いた実験結果から，層流中では $\eta$ は $\operatorname{Pr}$ とともに増加するが，乱流中では その影響は小さいことが示されている ${ }^{(11)}$. しかしながら, これらの一般的な傾向を説明する物理的機構は, 完全

* 原稿受付 2012 年 3 月 30 日

*1 正員, 大阪市立大学大学院工学研究科（干558-8585 大阪府大阪市住吉区杉本 3-3-138）

*2 学生員, 大阪市立大学大学院工学研究科

E-mail: katoh@mech.eng.osaka-cu.ac.jp 
には明らかにされていない。

本研究では，伝熱促進体として渦発生体を例にとり，層流および乱流中に取り付けたとき，Prの変化に対する 効率 $\eta$ の挙動について考察を行う. 1980 年以降, 渦発生体により流れ中に縦渦を誘起して伝熱促進を図る手法に ついて, 数值計算や実験に基づいた多くの研究報告がなされてきた. 渦発生体は比較的簡単に壁面に加工できる こと，ならびに誘起された縦渦は減衰しにくく，比較的低い圧力損失増加に対して良好な伝熱促進が可能になる ことが長所として指摘されている(12)(13). 最近では，色々な形状の渦発生体に対する効率の評価について，実験や 数值計算において広範な検討が行われている(14)-(16). また，フィンアンドチューブ熱交換器を対象に，フィン壁面 に渦発生体を設置して，はく離による抵抗増加ならびに伝熱性能の劣化の改善を図る取り組みも多くなされてい る ${ }^{(17)-(19)}$. 渦発生体を実際の装置内で用いるとき, 壁面の一部を切り起こして設置する工法がよく用いられる.よ り正確な性能の把握のため, 切り起こした後の孔の有無の伝熱性能への影響についても, しばしば議論が行われ ている(5)(17)(19)(20)。これまでの数多くの研究報告により, 渦発生体の幾何学的形状や設置位置の伝熱促進や圧力損 失に及ぼす影響，また渦構造と伝熱の関係などについて，工学的に有益な知見が得られている．しかしながら， 層流あるいは乱流中に渦発生体を取り付けた場合や，作動流体の物性の変化が効率に及ぼす影響など，基礎的な メカニズムを詳細に議論した報告はほとんど見当たらない. 本研究では, 平行平板間流路の壁面に単純なデルタ 翼を取り付けた場合を対象として，様々な条件下で速度場，温度場の直接数值計算を行う。既報では，滑面から

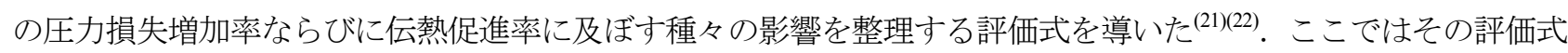
を用い，様々なプラントル数において層流，乱流中に渦発生体を取り付けたとき，圧力損失や伝熱促進に及ぼす 乱れの影響や，壁面近傍の対流熱流束の影響について考察を行う．また，上述した翼の切り欠き孔の有無が効率 に及ぼす影響についても検討する.

\section{2. 対象流路および数值計算方法}

本研究では, 図 1(a)のような流路高さ $H=2 b$ の平行二平板間流路の下側壁面に, 図 1(b)に示すデルタ翼状の渦 発生体を設置した場合の流れ場, 温度場を数値シミュレーションにより求めた. 座標系として, 図 1(a)のように 流れ方向, 壁面垂直方向, スパン方向にそれぞれ $x, y, z$ 軸を取る. デルタ翼について, 経験的に圧力損失に対す る伝熱促進率が最も良好な形状として，ここでは迎え角 $\beta=30^{\circ}$ ，アスペクト比が 1.5 のものを対象とした ${ }^{(23)}$. な お，図 1(b)のように，翼は壁面の一部をパンチして作成されており，翼直下には切り欠き孔が存在する，孔の影 響を扱った従来の研究例として，孔の存在が伝熱性能にほとんど影響しないとする報告や(19)(20), 熱伝達ならびに

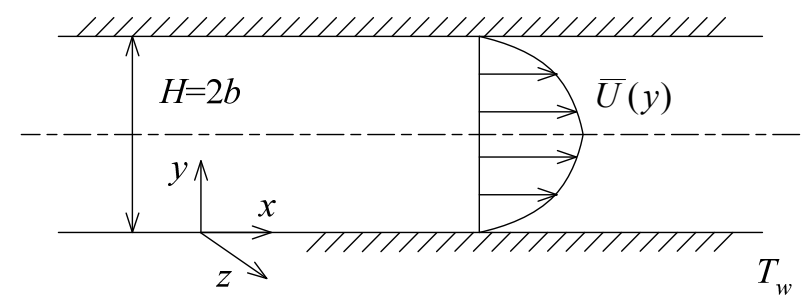

(a)Smooth channel and coordinate system

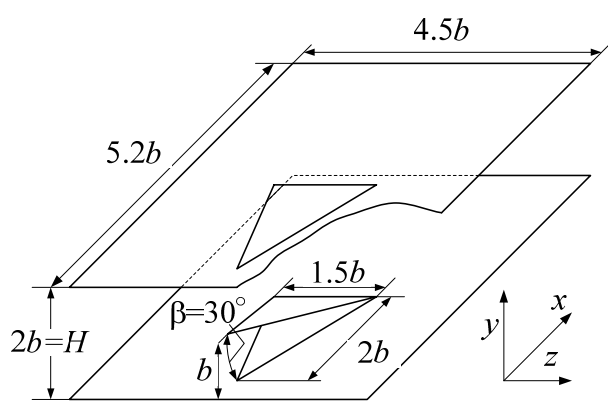

(b) Channel with delta wing-type vortex generator

Fig. 1 Schematic of vortex generator 
圧力損失両者が低減するとした報告も認められる ${ }^{(5)}$. しかしながら，孔の存在による流れ場，温度場の変化と伝 熱性能との関係を具体的に議論した例は認められない。ここでは, 翼直下に孔のある場合，ない場合それぞれに ついて数值計算を行い，伝熱性能の変化についても検討を行う.

複数の乱れ促進体を流れ方向に等間隔で設置するとき,一般に 5 6 個目以降の下流域では, 伝熱特性がほぼ一 定に落ち着くことが知られている(24). ここでは, 壁面に周期的に渦発生体を設置した場合の発達した速度場およ び温度場について, 図 1(b)に示寸流路一単位を対象として, 以下の運動・エネルギー方程式の直接数值計算を行 った.

$$
\begin{aligned}
& \frac{\partial \widetilde{u}_{i}^{+}}{\partial t^{+}}+\widetilde{u}_{j}^{+} \frac{\partial \widetilde{u}_{i}^{+}}{\partial x_{j}{ }^{+}}=-\frac{\partial \widetilde{p}^{+}}{\partial x_{i}{ }^{+}}+\nabla^{2} \widetilde{u}_{i}^{+} \\
& \frac{\partial \widetilde{T}^{+}}{\partial t^{+}}+\widetilde{u}_{j}+\frac{\partial \widetilde{T}^{+}}{\partial x_{j}{ }^{+}}=\frac{1}{\operatorname{Pr}} \nabla^{2} \widetilde{T}^{+}
\end{aligned}
$$

上式において, ${\tilde{u}_{i}}^{+}$はそれぞれの座標方向の瞬時速度, $\widetilde{T}^{+}$は瞬時温度である. 添え字の+は, 動粘度 $v$, 摩擦速度 uならびに壁面熱流束 $\dot{q}$ を用いた無次元量を表している，温度は，次式のように無次元化を行っている.

$$
\widetilde{T}^{+} \equiv \frac{\rho C_{P} u_{\tau} \widetilde{T}}{\dot{q}}
$$

ここで， $\rho, C_{P}$ はそれぞれ密度および定圧比熱である. 式(1)，(2)の境界条件として，xおよび $z$ 方向に周期境界 条件を適用し, 流路壁面ならびに翼面で温度一定の条件を課した，なお，孔がある場合，上下壁面の孔の位置に も周期条件を課している.

SMAC 系解法を用いた直接数值計算により, 式(1)および式(2)の解を求めた ${ }^{(25)}$. 空間の離散化はスタガード格子 を用いた 2 次精度差分法により行い, 時間の離散化には 2 次精度の Adams-Bashforth 法を用いた. $y$ 方向には不等 間隔格子を採用しており, 壁面近傍での最小格子間隔は $\Delta y^{+}=0.77$, 中心軸近傍での最大間隔は $\Delta y^{+}=3.3$ である. 図 1(b)の翼面が, 構造格子における $x$ および $y$ 方向速度の定義点を通るように設定し, 速度, 圧力および温度の 境界条件を満足するように計算を行った ${ }^{(22)}$. 翼付き流れについて, 設定メッシュ数は $x, y, z$ 方向にそれぞれ, 100 $\times 100 \times 140$ とした. 一般に, プラントル数の増加とともに温度乱れの最小スケールが小さくなるため, メッシュ 数を $\operatorname{Pr}^{1 / 3}$ で増加させる必要がある ${ }^{(26)}$. 上記メッシュ数における精度の確認のため, 計算精度の劣化が予想される $5 \leqq P r \leqq 10$ において, メッシュ数を各方向に 3 倍にした条件で数值計算を行った. その結果, 4 章で議論する種々 の計算值は，上記設定メッシュ数に対する值と $3 \%$ 程度の差で一致することが認められた。本研究では主に時間 ならびに空間的に平均した量を対象とするため, メッシュ数の影響はそれほど顕著でなく，上記設定メッシュ数 に対する結果を用いることとした，なお，滑面流れに対する本研究の数值計算結果から求めた摩擦係数や種々の

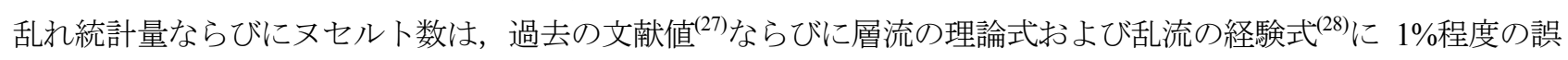
差で一致することを確認している.

滑面流路および翼付き面流路における圧力損失と熱伝達率を比較するために, 単位スパン長さ当たりの流量 $\Gamma$ $\left[\mathrm{m}^{2} / \mathrm{s}\right]$ および壁面温度 $T_{w}$ と流路内の平均バルク温度 $T_{b}$ の差 $\left(T_{w}-T_{b}\right)$ を同一とした. 層流, 乱流中に翼を取り付け たときの挙動について検討するため, レイノルズ数 $R e\left[\equiv\left(U_{\mathrm{av}} \times 2 H / v\right), U_{\mathrm{av}}\right.$ : 断面内平均流速, $v$ : 動粘度 $]$ を層流 $R e=$ 500, 2000 および乱流 $R e=9000$ として, プラントル数 $P r=0.1 \sim 10$ の範囲で数值シミュレーションを行った. 表 1 に, 本研究における計算条件を示寸.

Table 1 Calculation conditions

\begin{tabular}{|l|l|}
\hline Wall conditions & $\begin{array}{l}\text { Solid smooth wall, } \\
\text { Pierced wall with vortex generator, } \\
\text { Solid wall with vortex generator }\end{array}$ \\
\hline Reynolds number & $500,2000,9000$ \\
\hline Prandtl number & $0.1,0.2,0.5,0.71,1,2,5,7,10$ \\
\hline
\end{tabular}




\section{3. 効率の評価式}

既報において, 流路壁面に任意の形状の伝熱促進体を設置したとき, 滑面からの圧力損失増加率 $\left(\equiv D^{\prime} / D, D^{\prime}\right.$, $D$ : 翼付き面流路および滑面流路の圧力損失） と伝熱促進率（三Nu' $/ N u . N u$ ', Nu : 翼付き面流路および滑面流路 のヌセルト数）を整理する評価式を導出した．これら 2 つ式を用い，様々なプラントル数 $\operatorname{Pr}$ において，層流お よび乱流中に渦発生体を取り付けたとき，効率 $\eta$ に及ぼす種々の影響について検討を行う．以下に，評価式の導 出を簡単に述べる，詳しい内容は，文献(21)および(22)を参照されたい.

\section{$3 \cdot 1$ 圧力損失増加率}

翼付き面流路に対し, 時間平均した $x$ 方向ナビエ - ストークス方程式を, 流路内の $x-z$ 平面内で積分平均する. その結果を $y$ 方向に積分寸ると，次の応力釣り合い方程式を得ることができる.

$$
\frac{D^{\prime}}{D}\left(1-\frac{y^{+}}{b^{+}}\right)=\frac{\overline{d \overline{U^{\prime+}}}}{d y^{+}}-\overline{\overline{u^{\prime+} v^{\prime+}}}+d_{V G}^{\prime+}
$$

ここで, $=$ は時間 $-x z$ 平面内平均值を表す. 上式中の壁指標による無次元化において, 滑面流れにおける摩擦速度 を用いている. その結果, 式(3)左辺には圧力損失増加率 $D^{\prime} / D$ が現れている. なお，式(3)中の各従属変数に施し た'は，翼付き面での值を表している． $\bar{U}^{\prime}=\overline{\bar{U}}^{\prime}(\mathrm{y})$ は $x$ 方向時間一平面内平均速度， $u^{\prime}, v^{\prime}$ は，それぞれ $x, y$ 方向 の平均からの変動速度成分である. 式(3)の右辺第 3 項は, $y^{+} よ り$ 上の翼面部分からの抗力を表している. 上式 の流路内積分值を，滑面に対する同様の応力釣り合い方程式の積分值で辺々除すことにより，圧力損失増加率に ついて以下の評価式を得ることができる.

$$
\frac{D^{\prime}}{D}=\frac{\int_{0}^{b}\left(\frac{d \overline{{U^{\prime+}}^{+}}}{d y^{+u^{\prime+} v^{\prime+}}}+d d_{V G}^{\prime}\right) d y^{+}}{\int_{0}^{b^{+}}\left(\frac{d \overline{U^{+}}}{d y^{+}}-\overline{u^{+} v^{+}}\right) d y^{+}}
$$

分母の滑面流れに対する諸量は，通常の時間平均值を表している，滑面流れが層流のとき，式(4)分母中のレイ， ルズ応力は 0 となる．右辺の分子に現れる各積分量を分母で除した值は，滑面からの圧力損失増加への，流路内 でのそれぞれの平均的な寄与率を表す. 翼付き流路に対する数值計算結果を式(4)に用いることにより, 粘性応力, 乱れによる運動量輸送ならびに翼面からの抗力の, 圧力損失増加への寄与を評価することができる.

\section{$3 \cdot 2$ 伝熱促進率}

壁温一定の条件に対する，翼付き面流路内の平均エネルギー方程式を考える．局所瞬時温度を次式のように表 す.

$$
T_{w}-\widetilde{T}=\left(T_{w}-\overline{\overline{T_{b}}}\right) f^{\prime}(y)+\theta^{\prime}
$$

$T_{W}$ は壁面温度である. また, $\overline{\overline{T_{b}}}$ は, 図 1(b)の流路 1 単位内での平均バルク温度で, $\theta$ 'は平均からの温度変動であ る. $f^{\prime}(y)$ は発達した無次元平均温度分布で, 次式で定義する.

$$
f^{\prime}(y) \equiv \frac{T_{w}-\overline{\bar{T}}}{T_{w}-\overline{\overline{T_{b}}}}
$$

ここで, 時間平均エネルギー方程式を $x-z$ 平面内で積分平均し, さらに $y$ 方向に積分すると, 次の熱流束に対す る釣り合い式を得ることができる. 


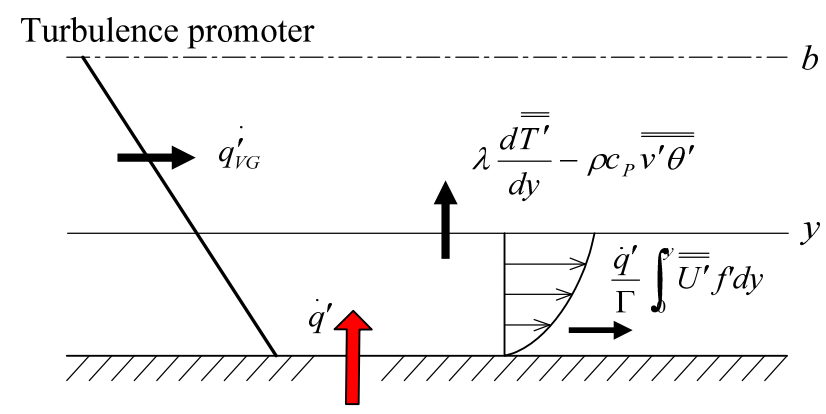

Fig. 2 Heat balance in VG channel

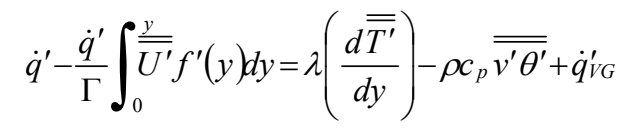

ここで, $\overline{\bar{T}}$ は壁温からの温度差として再定義されている. $\dot{q}^{\prime}$ は壁面からの熱流束, 「はスパン方向単位幅当たり の体積流量で，右辺の れは熱伝導率である．図 2 は，式(7)が表す熱流束の収支を模式的に示したものである．式 (7)左辺は $y$ より上の流体に伝えられる熱量を表し, 壁面からの熱流束から対流により持ち去られる分を差し引い

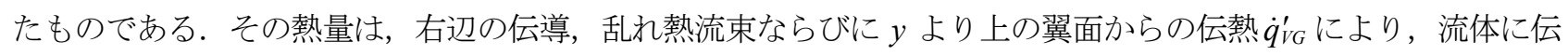
えられることを示している.

式(7)を，滑面の摩擦速度ならびに壁面熱流束を用いて無次元化すると，以下の式を得ることができる.

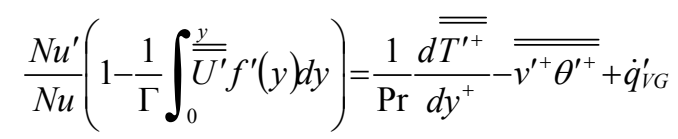

バルク温度を滑面と同一に設定し，滑面の壁面熱流束で無次元化を行った結果，左辺に伝熱促進率 $\left(N u^{\prime} / N u\right)$ が現 れる. 3.1 節の圧力損失と同様，翼付き流路に対する式(8)を $y$ 方向に積分し，滑面流路に対するエネルギー方程 式の積分值で辺々を除す，その結果，伝熱促進率の評価式として次式が得られる.

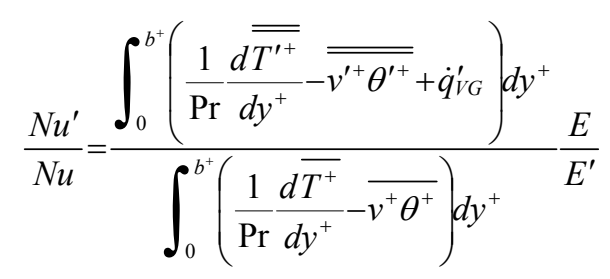

滑面流路が層流のとき，右辺分母の乱れ熱流束 $=0$ である. 上式において， $E$ および $E$ ' は以下のように定義さ れる.

$$
E=\int_{0}^{b^{+}}\left\{1-\frac{1}{\Gamma} \int_{0}^{\frac{y}{U}} f(y) d y\right\} d y^{+}, \quad E^{\prime}=\int_{0}^{b^{+}}\left\{1-\frac{1}{\Gamma} \int_{0}^{\frac{y}{U^{\prime}}} f^{\prime}(y) d y\right\} d y^{+}
$$

$E$ および $E$ ’ は，それぞれ滑面および翼付き面流路における壁面からの熱流束のうち，対流により持ち去られる 熱量を差し引いた残りの割合を表している. 寸なわち， $E$ の值が小さいほど流れ方向の対流熱流束が増し，熱抵 抗が小さくなることに対応する. 式(9)の右辺における $E / E^{\prime} の$ 効果は, 応力と伝熱の物理的なメカニズムの違いに より生じるもので，圧力損失増加率の評価式(4)には現れない効果である ${ }^{(22)}$. 式(4)と同様，式(9)右辺分子の各積 分量を分母で除した值は，それぞれ伝導，乱れ熱流束ならびに翼面からの伝熱の，全体の伝熱促進率への寄与を 


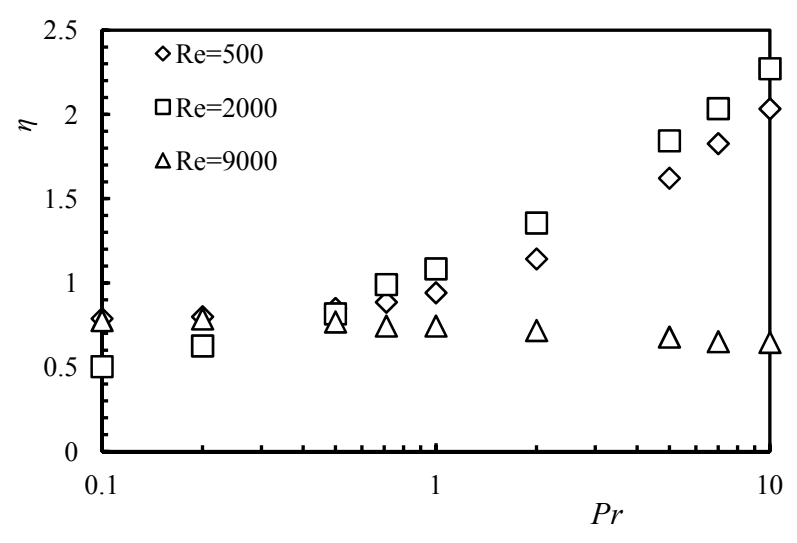

(a) Efficiency index

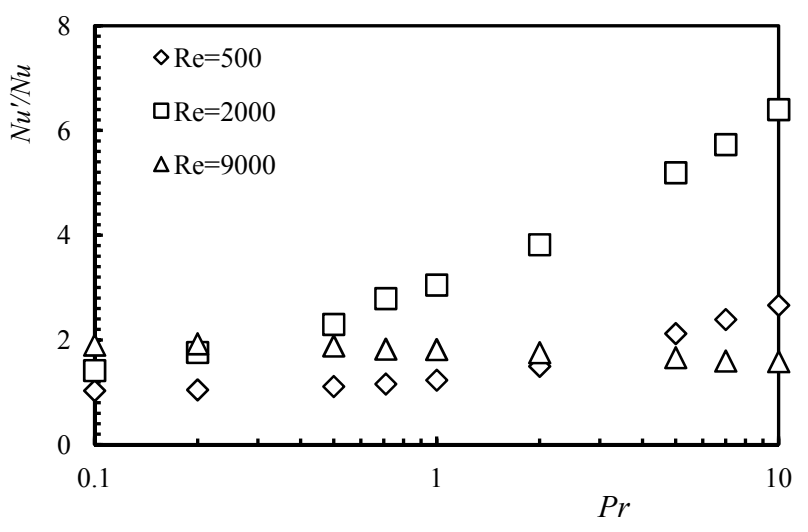

(b) Ratio of heat transfer enhancement

Fig. 3 Heat transfer performance for various Prandtl numbers

表している. 式(9)中の各項の数值計算結果を求めることにより，その平均的な寄与について議論することができ る.

\section{4. 数值計算結果および考察}

\section{$4 \cdot 1$ 効率および伝熱促進率に及ぼす Pr の影響}

直接数值シミュレーションにより得られた結果に基づき, 効率に及ぼすプラントル数 $\operatorname{Pr} の$ 影響について検討す る. 翼の切り欠き孔の有無について，両者のPrに対する定性的な傾向は同じであったので，ここでは孔ありの流 路について考察を行う，孔の有無の影響については，次節で検討する．図3(a), (b)に，各レイノルズ数に対する 効率および伝熱促進率 $\left(\mathrm{N} u{ }^{\prime} / \mathrm{Nu}\right)$ のプラントル数 $\operatorname{Pr}$ に対する変化の様子を示す. ここで, 効率 $\eta$ を次のように定義 している.

$$
\eta=\frac{N u^{\prime} / N u}{D^{\prime} / D}
$$

$P r$ に対して圧力損失は変化しないので, 図 3(a), (b)からもわかるように, 当然ながら $\eta$ と $\left(N u^{\prime} / N u\right)$ の両者は $P r$ に 対して同じ傾向となる. 図 3(a)より, 効率 $\eta$ は, 層流においてプラントル数の増加とともに上昇する傾向が見ら れた. $R e=500$ では, $P r \geqq 2$ で 1 より大きく, Re=2000のときは $P r \geqq 1$ で 1 より大きくなり, 圧力損失増加 率以上の伝熱促進率が得られる結果となった. $\mathrm{Re}=500$ と 2000 を比較すると, $P r \leqq 0.5$ のときは $R e=500$ の方 が $R e=2000$ よりも効率は良好で, $\mathrm{Pr} \geqq 0.5$ では $\mathrm{Re}=2000$ の方が良好となる結果となった. 一方, 乱流の効率は, すべての Pr に対して 0.6 0.7 程度とほぼ一定の值をとり, Pr とともにわずかではあるが減少する傾向を示した. 乱流における効率は，層流ほどプラントル数の影響を強く受けないといえる. 図 3(b)の伝熱促進率を見ると, 3 種類のレイノルズ数では $\mathrm{Re}=2000$ が最大で, $\mathrm{Pr}=10$ のときには, 滑面から 6 倍以上の伝熱促進が認められた. Pr が大きくなるほど, 他の Re との差は大きくなる，なお，前報では，滑面と翼付き流路において，壁温と流路中 心温度との差を同一にしていること, ならびにレイノルズ数の定義が本報告と異なることから, 図 3 中の $\mathrm{Pr}=1$ に対する $\eta$ や伝熱促進率の值に若干の差異が生じていることに注意されたい(22). 上述の効率ならびに伝熱促進率 に及ぼす種々の効果について検討を行う. 伝熱促進率の整理式(9)において, 分子各項を分母で除した值の数值計 算結果を図 4 に示寸. 図 4(a)には, 伝導の寄与ならびに翼面からの伝熱の寄与が合わせて示されている. また図 4(b)は乱れ熱流束の寄与, さらに図4(c)に対流熱流束の効果を表す $E / E^{\prime}$ の值が示されている. まず, 図4(a)におけ る伝導の効果は, 乱流 $R e=9000$ では低 $P r$ を除きその寄与は小さいが，層流 $R e=500,2000$ では, 翼付き面でもそ の寄与率は比較的大きく, Pr に対して若干減少寸る傾向を示寸，これは，図4(b)のように，層流では温度乱れが $\operatorname{Pr}$ とともに著しく増加する結果, 温度分布が滑面流れに比べて平坦化されることにより, 温度勾配の平均值が減 


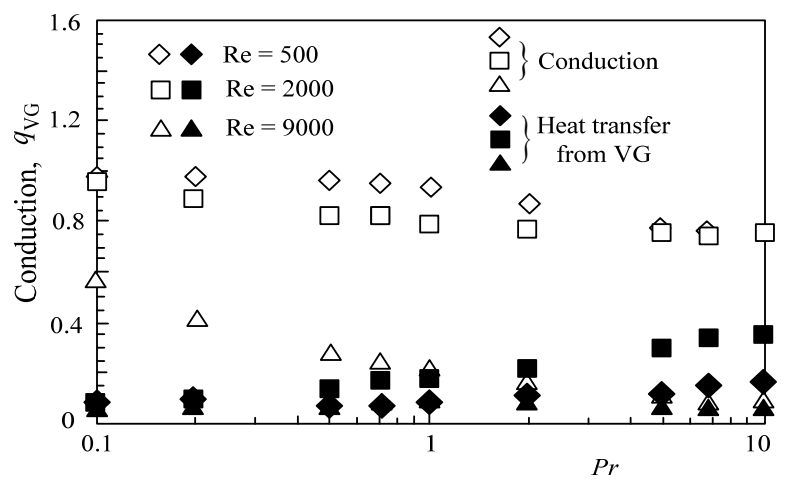

(a) Conduction and heat transfer from VG surface

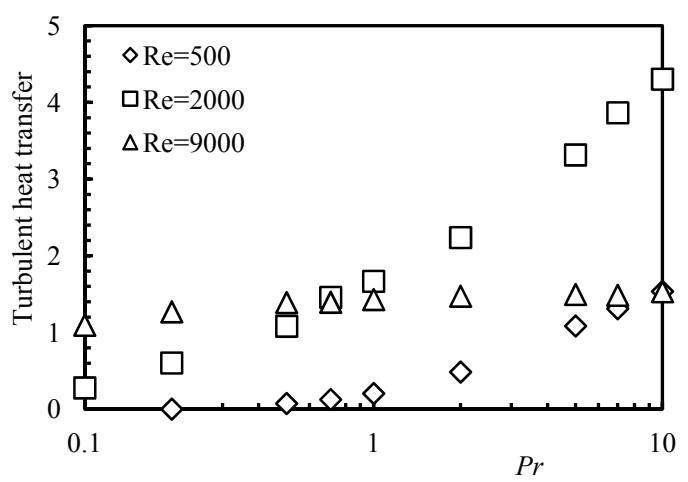

(b) Turbulent heat transfer

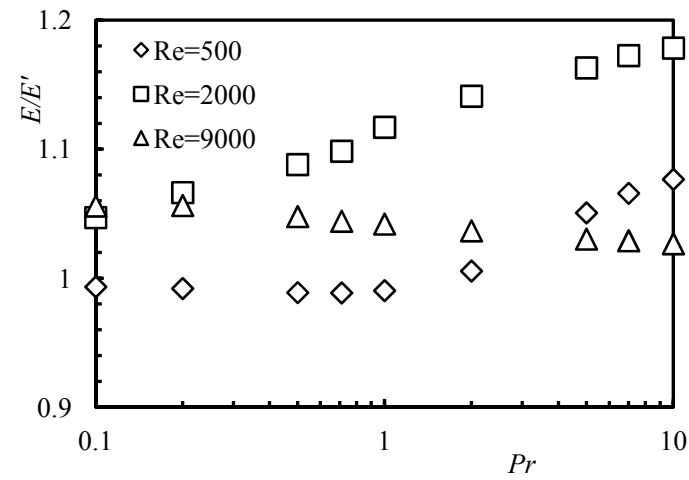

(c) Convection near wall

Fig. 4 Contribution of each term in Eq. (9) to heat transfer enhancement $(\mathrm{Nu}$ ' $/ \mathrm{Nu})$

Table 2 Contributions of each term to drag increase in wing channel

\begin{tabular}{|c|c|c|c|c|}
\hline Re & Viscous drag & Reynolds stress & Drag on VG & $D^{\prime} / D$ \\
\hline \hline 500 & 0.963 & 0.156 & 0.197 & 1.31 \\
\hline 2000 & 0.804 & 1.383 & 0.618 & 2.81 \\
\hline 9000 & 0.233 & 1.411 & 0.768 & 2.44 \\
\hline
\end{tabular}

少したことによる.図 4(a)中, 翼面からの伝熱の值は, 層流 $R e=500$ と 2000 では $P r$ ともに若干増加するものの, いずれの Re においても，伝熱促進率全体に対してわずかな寄与しかない，ここで，翼の伝熱および抗力への寄 与の比較を行う. 表 2 に, 各レイノルズ数における圧力損失増加率の整理式(4)中, 右辺各項の寄与を示す. 表中 の翼の抗力 $d_{\mathrm{VG}^{\prime}}$ の寄与を見ると, $R e=500$ の低速の場合にはそれほど大きくないが, 他のレイノルズ数では，全抗 力に対して 20\%から 30\%程度の寄与を与えている. 翼による抗力の増加は，伝熱以上に圧力損失に影響を与え， 特に高レイノルズ数における効率 $\eta$ の亜化の原因となる(21).

次に，翼の効果を最も特徵的に表す図 4(b)の乱れ熱流束の寄与について検討を行う. 図 4(b)より，層流 $R e=500$ および 2000 において, $R e=500$ では乱れ熱流束の寄与は小さいものの，Pr とともにそれらの值は顕著に増加する ことがわかる. 一方, 乱流 $R e=9000$ の場合には, Pr に対する変化はわずかである. 以上の $\operatorname{Pr}$ に対する傾向は図 3 と類似であり，乱れ熱流束の寄与の挙動が，伝熱促進率に大きな影響を与えているといえる．層流中に翼を設 置した場合，熱拡散の効果が小さい高プラントル数ほど温度乱れは大きくなる．滑面層流流れには乱れがないた め, 翼で発生した温度乱れによる輸送量が直接伝熱促進に影響を与える，以上のことから，層流では Prとともに

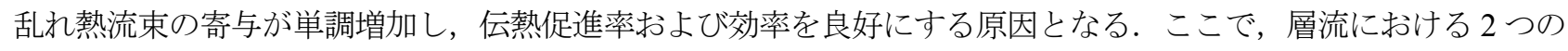
レイノルズ数, $R e=500$ と 2000 について比較する. 前者の低レイノルズ数では, ここで用いた翼により発生する 
Table 3 Contributions of each term to heat transfer enhancement in wing channel

(a) $\operatorname{Pr}=0.2$

\begin{tabular}{|c|c|c|c|c|c|c|}
\hline Re & Conduction & Turbulent heat flux & $\begin{array}{c}\text { Heat transfer } \\
\text { from VG }\end{array}$ & E/E' & $N u^{\prime} / N u$ & $\eta$ \\
\hline 500 & 0.985 & 0.001 & 0.045 & 0.992 & 1.045 & 0.80 \\
\hline 2000 & 0.938 & 0.205 & 0.071 & 1.066 & 1.760 & 0.63 \\
\hline 9000 & 0.428 & 1.269 & 0.106 & 1.056 & 1.926 & 0.79 \\
\hline
\end{tabular}

(b) $\operatorname{Pr}=1$

\begin{tabular}{|c|c|c|c|c|c|c|}
\hline Re & Conduction & Turbulent heat flux & $\begin{array}{c}\text { Heat transfer } \\
\text { from VG }\end{array}$ & E/E' & $N u^{\prime} / N u$ & $\eta$ \\
\hline 500 & 0.938 & 0.205 & 0.071 & 0.990 & 1.231 & 0.94 \\
\hline 2000 & 0.799 & 1.667 & 0.174 & 1.117 & 3.047 & 1.08 \\
\hline 9000 & 0.212 & 1.430 & 0.096 & 1.042 & 1.815 & 0.74 \\
\hline
\end{tabular}

乱れが小さい. 前出の表 2 より, 翼面の抗力およびレイノルズ応力は, $R e=500$ から 2000 の流速変化に対して大 きく増加しているのがわかる. 表 3 に $P r=0.2$ と 1 のとき, 各レイノルズ数において, 伝熱促進率に及ぼす各項 の寄与の值を示寸. 表 3 中の層流 $R e=500$ と 2000 に注目寸る. 表 3(a)の $P r=0.2$ では大きな熱拡散の効果により, 表 2 中のレイノルズ応力の寄与と比べ，乱れ熱流束の值が著しく小さいことがわかる．このことが，層流におい て低 $P r$ における効率が 1 よりも小さくなる原因となる. 表 2 より翼の抗力とレイノルズ応力の值は $R e=2000$ の 方がかなり大きく, その分だけ $R e=500$ よりも効率がさらに低くなる. しかしながら, $\operatorname{Pr}$ が増加して表 3(b)の $P r=1$ 程度になると, $\mathrm{Re}=500$ に比して翼による乱れの大きい $\mathrm{Re}=2000$ の熱流束の值が急激に増加する結果, 効率の値 が逆転して $R e=2000$ の方が大きくなる.

図 4(b)に示した, 乱流 $R e=9000$ における乱れ熱流束の寄与について考察する. 乱流では, 上述の層流と異なり, 滑面流れにおいてもともと乱れが存在する. Prが大きくなると熱拡散の効果が弱くなるため, 滑面流れにおける 温度乱れは, $P r$ とともに単調に増加する。一方, 流速の大きい乱流中に翼を設置した場合, 強制的に発生する強 い乱れは，滑面流れほど $P r$ の影響を強く受けない。したがって，図 4(b)に見られるように，乱れ熱流束の寄与は $\operatorname{Pr}$ とともにあまり変化しないと考えられる. 図 5 は, 滑面と翼付き面の乱れ熱流束の積分平均值の比 $R$ の $P r$ に 対する変化を見たものである. 上述した滑面と翼付き面での乱れの挙動により， $R$ の值は $P r$ とともに若干減少 する傾向を示寸.このことが, 図 3 に示される $P r$ のきい領域での伝熱促進率が，層流のように良好とならない 原因の一つとなる.

伝熱促進に及ぼす対流熱流束 $E / E^{\prime}$ の効果について，図4(c)より検討を行う. 式(7)の左辺第 2 項は対流により壁 面近傍の熱が持ち去られる効果を表すが, その值が増加すると右辺各項への負荷が小さくなる結果, 熱抵抗が減 少して熱伝達率が増加する ${ }^{(22)}$. 図 4(c)より, 層流では $\operatorname{Pr}$ の増加とともに $E / E$ ' の值が大きくなり, 特に $R e=2000$

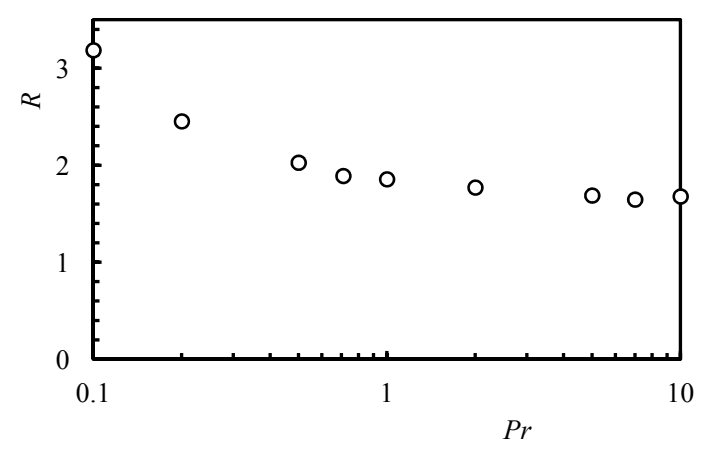

Fig.5 Ratio of turbulent heat transfer in VG channel to that in smooth channel 


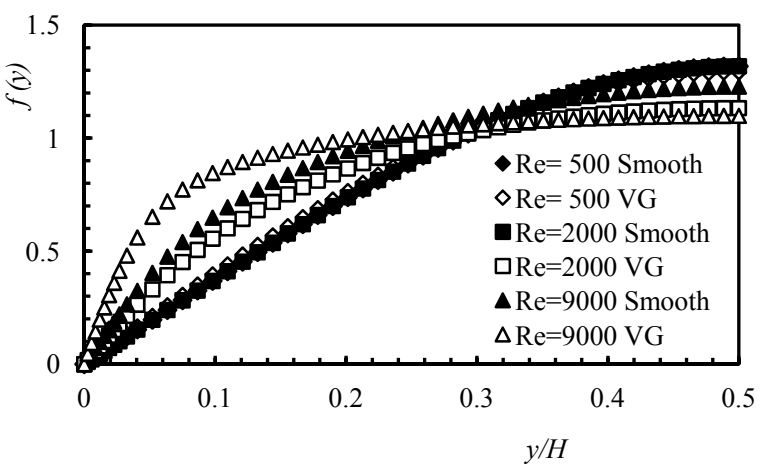

(a) $\operatorname{Pr}=0.2$

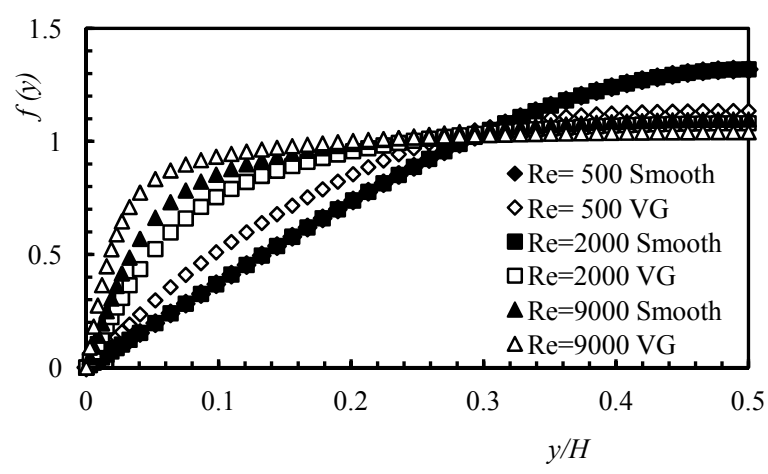

(b) $\operatorname{Pr}=7$

Fig. 6 Non-dimensional temperature distribution

では, $P r=10$ において約 1.2 となり，平均熱伝達率を滑面から $20 \%$ 押し上げる効果のあることがわかる. 一方乱 流では， $E / E^{\prime}$ は $P r$ とともに減少寸る傾向が見られ，その值も高々 1.05 程度にとどまっている. 図 6 は, 各レイ ノルズ数において，滑面と翼付き面の平均温度分布を比較したものである. 図(a), (b)にそれぞれ $P r=0.2$ と $P r=7$ の結果を示している．図中には，それぞれのレイノルズ数における滑面と翼付き面(VG)の結果が示してある．図 6 中の層流の温度分布は, 滑面流れの放物型の分布から平坦な分布へと変化するが，変化の度合いは高プラント ル数の方が顕著である.これは, Prの増加とともに熱拡散の効果が弱くなるため, 翼により与えられる乱れの攪 拌効果が強くなることの結果である. 式(10)の $E, E^{\prime} の$ 定義からわかるように, 温度分布が平坦化されるとその值 は小さくなり, 翼付き流路での伝熱が促進される結果となる. すなわち, 壁付近まで高温の流体が入りこむため, 対流熱流束が増加して滑面流れよりも熱抵抗が減少する.この効果は, 翼による擋䢁効果の大きい $R e=2000$ の方 が大きくなる. 乱流の場合を見ると, $P r$ が小さい図(a)の方が, 図(b)の $P r=7$ よりも変化の度合いが大きい. これ は，前述したように，低 $\operatorname{Pr}$ の滑面流れの温度乱れは抑制されており，翼により与えられる大きな擋乱の効果がよ り顕著に現れたためと考えることができる. この理由により, 乱流の $E / E^{\prime \prime}$ は, $P r$ とともに減少する傾向を示寸.

以上で述べたことから，層流においてプラントル数の増加とともに効率が上昇するのは，主に乱れ熱流束の寄 与と対流熱流束の効果を表す $E / E^{\prime}$ の増加によるものである. 一方, 乱流の場合は乱れ熱流束の滑面からの増加 割合ならびに $E / E$ 両者ともに, $P r$ とともに若干減少するため, 効率も $P r$ に対してやや減少する傾向を示すとい える.

\section{4·2 翼付き面のレイノルズ応カと乱れ熱流束の比較}

前述の圧力損失の内訳を示した表 2 において, $R e=2000$ と 9000 を比較すると, 乱れによる運動量輸送の圧力損 失への寄与は，両者でほぼ同じ 1.4 程度の值を取っていることがわかる. 一方，Pr=1 の伝熱促進の内訳を示した 表 3(b)において, 乱れ熱流束の寄与は, $R e=9000$ では運動量輸送とほぼ同じ 1.4 程度となっているのに対し, $R e=2000$ では運動量輸送を上回る 1.6 以上の值を取っているのがわかる. 寸なわち, 層流中に翼を取り付けたと きに発生する乱れは，運動量輸送以上に伝熱に寄与している。この原因について考察を行う.

図 7 は, $P r=1$ での $R e=2000$ および $R e=9000$ における, 各 $x$ 断面内で平均した乱れ熱流束ならびにレイノルズ 応力の, 流下方向への変化を示したものである. 図の横軸は, 流路長さ $L_{x}$ で無次元化した流下方向距離を表す. 図(a)が $R e=2000$, 図(b)が $R e=9000$ の場合である. 図中の 2 本の縦線は, それぞれ翼先端ならびに根元の位置を 表している. 層流, 乱流ともに翼が存在する領域で熱流束, レイノルズ応力とともに最小值を取り，その周辺で 乱れ熱流束がレイノルズ応力を上回る結果を示している. 層流の場合, 翼以外の領域で乱れ熱流束とレイノルズ 応力は大体等しく, 流路全体の平均として乱れ熱流束が上回る結果となる. 一方, 乱流の場合, 翼以外の領域に おいて，レイノルズ応力が乱れ熱流束を上回る結果，流路全体で両者はほぼ等しくなる．図７のような結果が得 られる理由について検討を行う。 


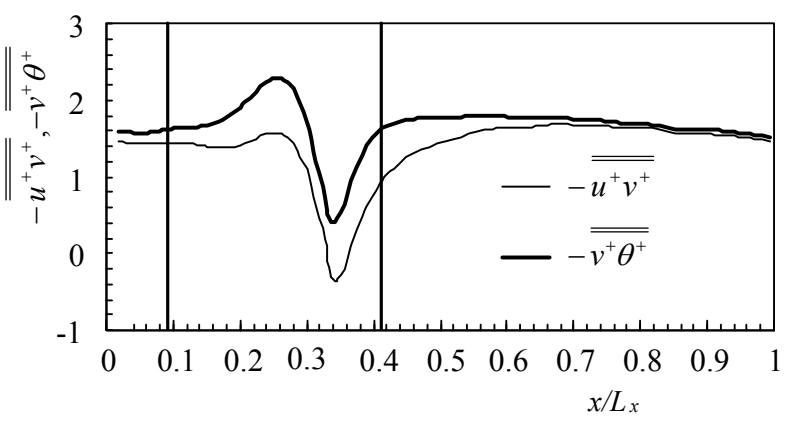

(a) $\mathrm{Re}=2000$

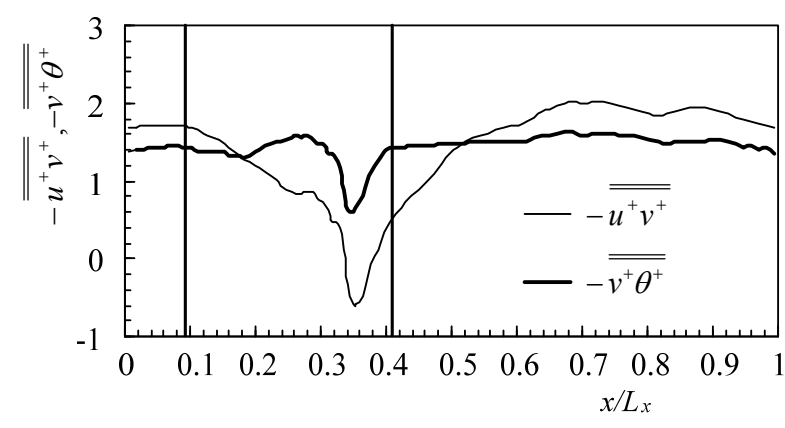

(b) $\operatorname{Re}=9000$

Fig. 7 Turbulent stress and heat transfer distributions in $x$ direction

図 8 は，Re=9000 において，レイノルズ応力および乱れ熱流束が極小值をとる箇所，すなわち図 7 の $x / L_{x}=0.35$ における断面内の流れ方向速度乱れと温度乱れの大きさの分布を色で表したものである. ここでは, 速度, 温度 乱れとして, 各位置における時間平均值と時間平均 $x z$ 平面内平均值との差が表示されている. 図 8 より, 翼に対 向する上側壁面の近傍(図中の A)に，速度，温度乱れともに正の大きな值をもつ領域が存在する.この位置には 一つ上の流路の翼切り欠き孔があり, 下側壁面の翼根元に向かって, 高速および高温の流体が噴き出している. 正の乱れが吹き出し速度によって流路中心方向に運ばれる結果，運動量ならびに熱輸送ともに大きな負の值をも つ.この領域の大きな負の輸送量の断面内平均への寄与は大きく, 図 7 において, レイノルズ忘力および乱れ熱 流束両者の值がともに極小值をもつ原因となる. 次に, 下側の壁面近傍の B において, 翼根元付近から巻き上が った一対の渦構造が認められる.この渦が成長し, 下流域で一対の縦渦を形成するのを確認することができる. 図 8(a)より, このような渦発生体後方の縦渦のコア領域の流速は周囲流体よりもかなり小さく, 乱れとして負の 值をもつ ${ }^{(12)}$. 図 9 は, 図 8 と同じ断面におけるレイノルズ応力と乱れ熱流束の分布を示したものである. なお, 壁面から垂直方向への速度 $v$ は, 中心軸を通過すると正負が逆転するため, 色が不連続に変化することに注意さ れたい. 図 8(a)のように翼の左右両端から低速の流体が巻き上げられ中心方向に輸送される結果，図 9(a)の B の 領域でレイノルズ応力は大きな正の值をとる.一方， $\mathrm{B}$ の中央部には翼先端からはく離した強い下向きの流れが

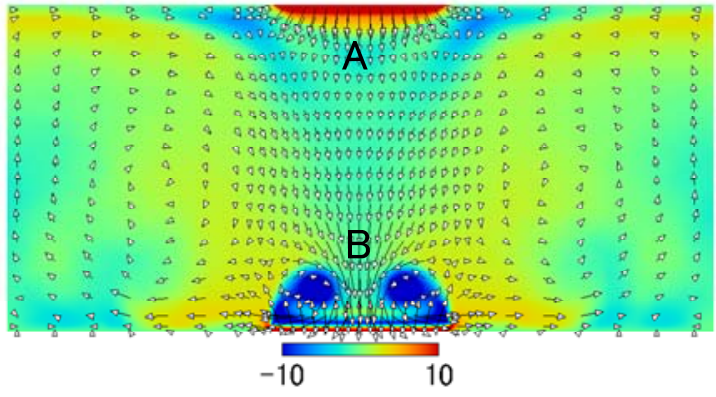

(a) Velocity fluctuation

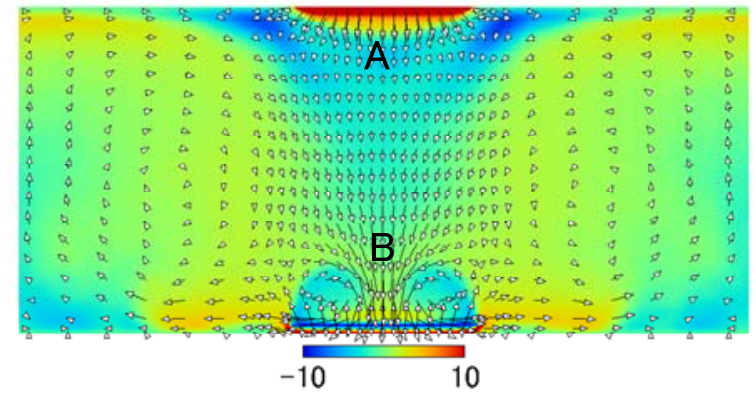

(b) Temperature fluctuation

Fig. 8 Streamwise velocity and temperature fluctuations at $x / L_{x}=0.35$

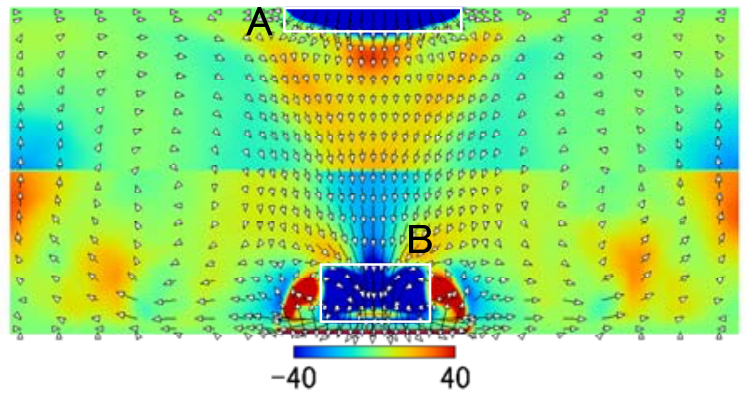

(a) Reynolds stress

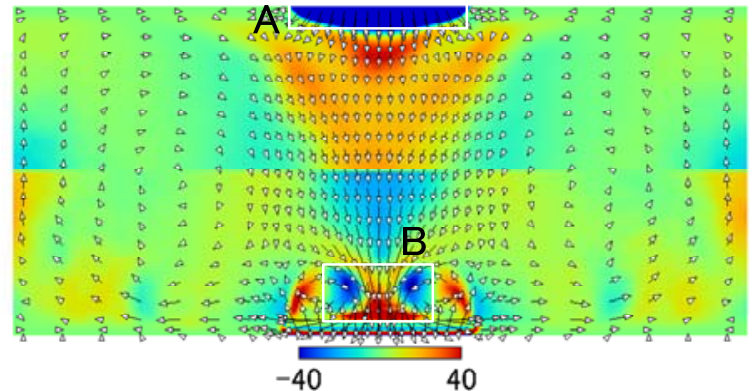

(b) Turbulent heat transfer

Fig. 9 Reynolds stress and Turbulent heat flux at $x / L_{x}=0.35$ 
存在し，低速流体を壁面方向に輸送するため，逆に負のレイノルズ応力が生じる結果となる．図 8(b)中のこの領 域での温度乱れを見ると，パッシブなスカラー量として，ベクトル量である速度とは異なる挙動をとる，すなわ ち瞬時值としてスカラー量は負の值を取ることはなく，中心付近から輸送される高温流体の寄与により，正の温 度乱れを示す結果となる. 図 9(b)より，この領域では正の熱輸送が認められ，図 9(a)の運動量輸送との強い非相 似性が現れている. 図 9 中の矩形領域 B 内での両者の值を計算し, 断面内平均值への寄与を求めた. 図 7(b)に 示された $x / L_{x}=0.35$ でのレイノルズ応力と乱れ熱流束の断面内平均值の差に対し, B 領域からの寄与が約 $90 \%$ を担 うことが示された. 翼根元後端に発生する渦内の負の乱れならびに翼先端からの下向き流れにより，レイノルズ 応力が大幅に減少し, 熱輸送に有利な結果となっているといえる. 以上の状況は, $R e=2000$ でも同様であった.

次に, $R e=9000$ において, レイノルズ応力が乱れ熱流束を卓越する結果が認められた図 $7(\mathrm{~b})$ の $x / L_{x}=0.7$ におい て, $R e=2000$ と 9000 に対する速度乱れの分布を図 10 に示寸. 図 10(b)の領域 C に認められるように, 翼により発 生した縦渦は $R e=9000$ の方が強力で，大きな負の速度乱れを持つとともに，渦対は対称軸から外向き上方に向か う誘導速度を受けることが認められた，これは，渦の壁面に対する鏡像ならびに，一つ横の流路に存在する渦か らの誘導速度によるものと考えられる. この状況を模式的に図 11 に示寸. 図 11 より, 翼から発生した渦は, ま ず壁面に対する鏡像から外向きの誘導速度を受ける ${ }^{(13)}$. また，隣の流路の渦から上向きの誘導速度を受ける. な お，流路側面が壁面によって閉じている場合にも，同様の効果が鏡像の渦から作用すると考えられる．したがっ て，渦は最初スパン方向外向きに移動し，徐々に隣の渦からの影響が強くなるため，上向きに移動するようにな る. その結果，低速の流体が上向きに輸送され，大きなレイノルズ応力が現れる. 前述の図 8(b)からわかるよう に, 温度場には渦中心に強い負の乱れはなく, 結果として $R e=9000$ においては, 平均としてレイノルズ応力が卓 越する結果となる. なお, 図 10(b)の負の乱れが認められる領域 C において, レイノルズ応力と乱れ熱流束の差 を計算し,その全体への寄与を調べたところ, 図 7(b)の $x / L_{x}=0.7$ で見られる差のほぼ $80 \%$ を担う結果が得られた. 層流の場合の図 10(a)においては, 翼から発生した渦の減衰が早く, 上向きの強い流れも認められない. 層流 $\mathrm{Re}=2000$ の場合, 渦発生体により誘起される縦渦の強度が弱く, 上述のような誘導速度による影響はほとんど認 められなかった，そのため, 運動量輸送と熱輸送に顕著な差は現れない. 以上のことより, $R e=2000$ では翼回り

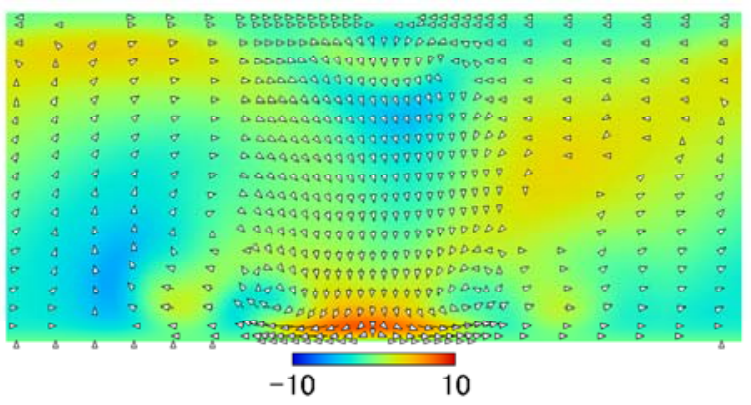

(a) $\mathrm{Re}=2000$

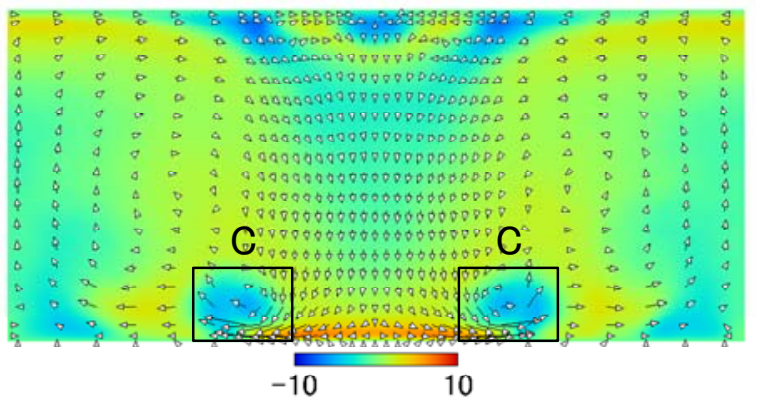

(b) $\mathrm{Re}=9000$

Fig. 10 Fluctuation of stream wise velocity at $x / L_{x}=0.70$

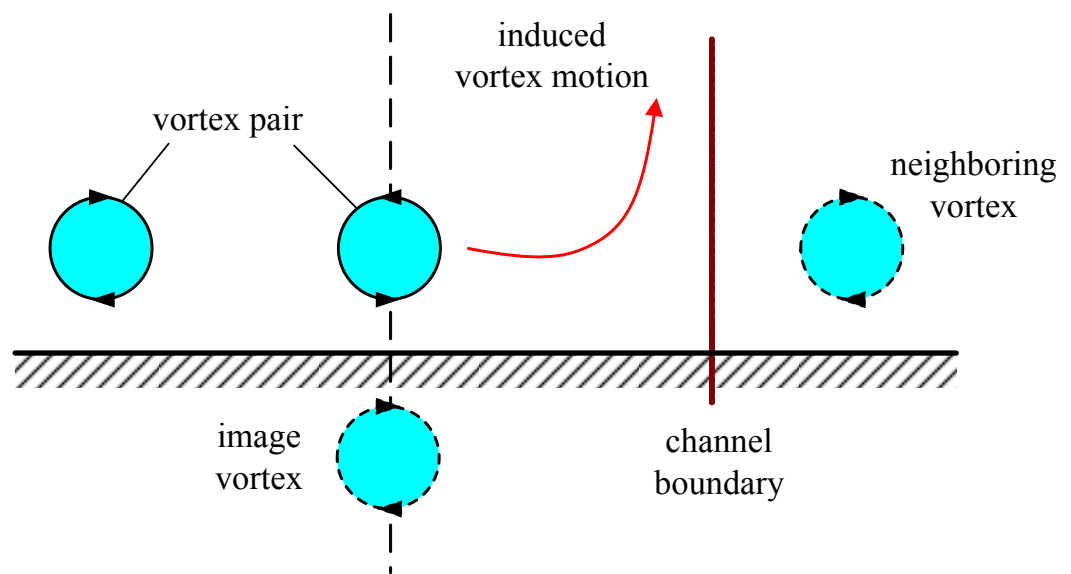

Fig. 11 Movement of longitudinal vortex 


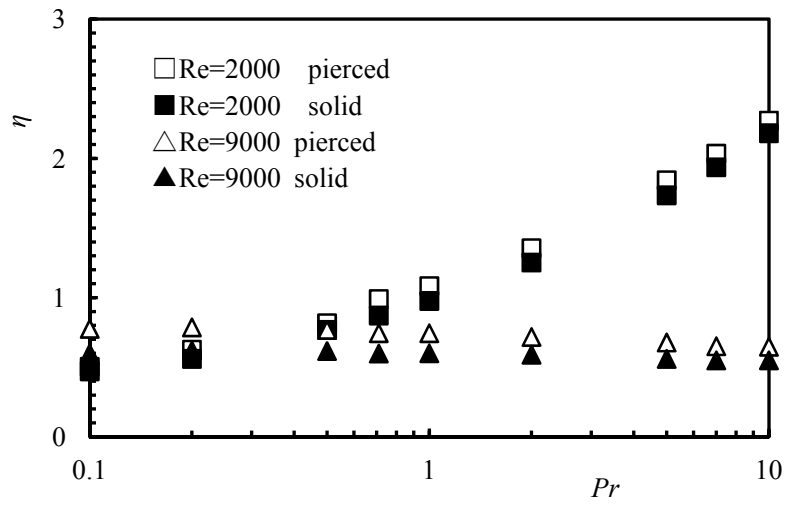

(a) Efficiency index

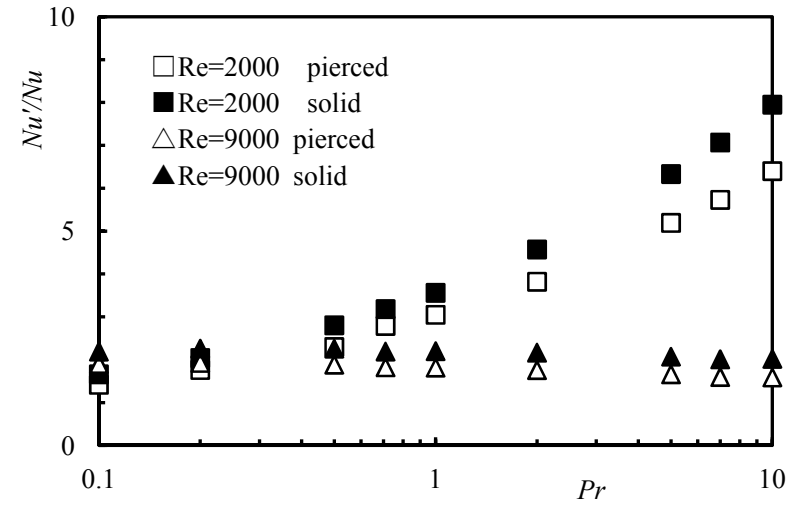

(b) Heat transfer enhancement

Fig. 12 Heat transfer enhancement and efficiency index of pierced wall

で熱輸送が顕著に上回る領域のみが存在するため, 流路全体で乱れ熱流束がレイノルズ応力を上回り, 効率を引 き上げる一因となる，一方， $R e=9000$ では強い縦渦の誘導速度により，レイノルズ応力が翼の下流域で卓越する ため, 乱れ熱流束とレイノルズ応力がほぼ均衡するといえる.

\section{$4 \cdot 3$ 孔の有無が効率に及ぼす影響}

図 12(a)，(b)に，孔がない場合の $R e=2000$ および 9000 に対する効率ならびに伝熱促進率の，Pr を示す．図には，比較のため，前述の孔ありの結果が白抜きのマークで示されている.

図より，層流および乱流において，効率は孔のある方が良好となるが，伝熱促進率は孔のない方が大きい，孔 が存在すると, 翼への近寄り流れの一部が孔を通過して流出してしまうため, 翼による乱れが小さくなる結果, 伝熱促進率は低下寸る.この状況は, 翼後方の断面内速度べクトルならびに温度乱れを表した図 13 より明らかで ある. 図(b)の孔なしの方が孔ありの図(a)よりも渦による攪拌が強いことがわかる. 孔なしの場合, 伝熱促進は孔 なしより大きくなるが，逆に効率は悪化する原因について，Re=9000 を例にとって考察を行う. ここでは，切り 欠き孔の有無が, 乱流応力と乱れ熱流束に対してどのように影響を及ぼすのか検討する. 図 14(b)は, 切り欠き孔 のない場合について, $P r=1, R e=9000$ における, 各 $x$ 断面内で平均した乱れ熱流束ならびにレイノルズ応力の流 下方向変化を表している. 前述の切り欠き孔ありの図 14(a)(図 7(a)の再掲)と比較すると, 孔が存在しない流路に おいては, 翼根元に近い領域において, 乱れ熱流束とレイノルズ応力両者の間に大きな差は認められない. 一方, 翼以外の領域において，レイノルズ応力が孔ありの場合よりもさらに卓越する様子が認められる. すなわち, 流 路全体を通じてレイノルズ応力が乱れ熱流束よりも増加する結果，効率が悪化する.

孔なし流路において, 図 9 と同じ位置 $\left(x / L_{x}=0.35\right)$ におけるレイノルズ応力と乱れ熱流束の分布を図 15 に示す. この場合，上側の壁面からの吹き出しがないため，孔あき流路のような強い負の輸送は現れない，一方，翼根元 の領域 B において, 図 9 と同じ現象が生じているのがわかる. 寸なわち, この領域ではレイノルズ応力が大きな 負の值を取っている. 孔なし流路では孔から流出する流れがないため, 翼根元に発生する渦の強度が増加する.

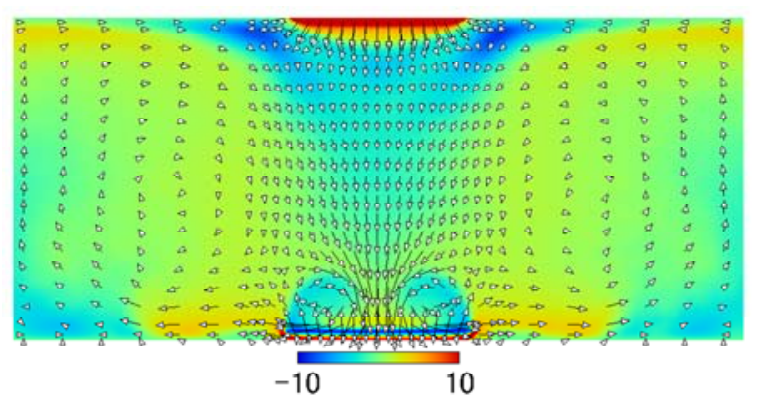

(a) Pierced wall

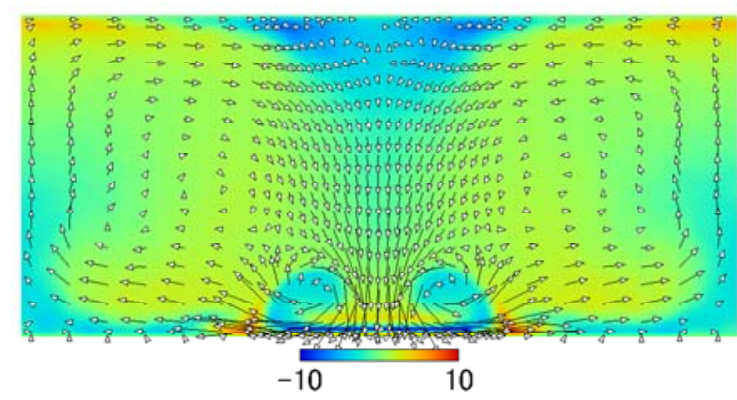

(b) Solid wall

Fig. 13 Distribution of temperature fluctuation $(\mathrm{Re}=9000)$ 


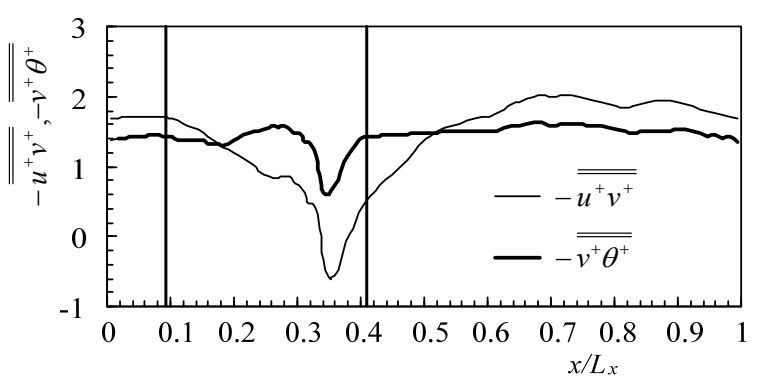

(a) Pierced wall

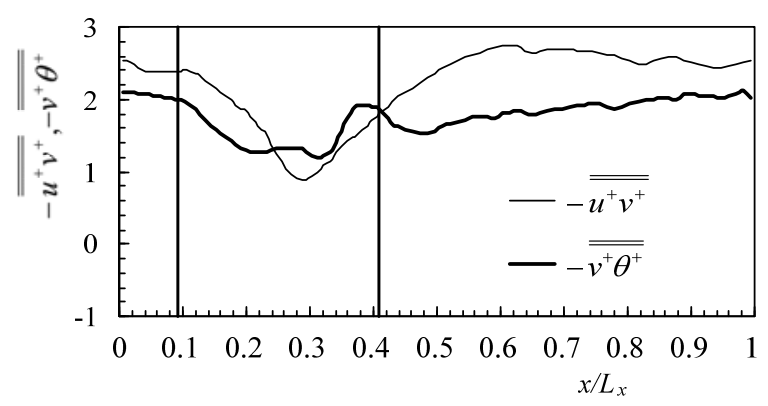

(b) Solid wall

Fig. 14 Turbulent stress and heat transfer distributions in $x$ direction

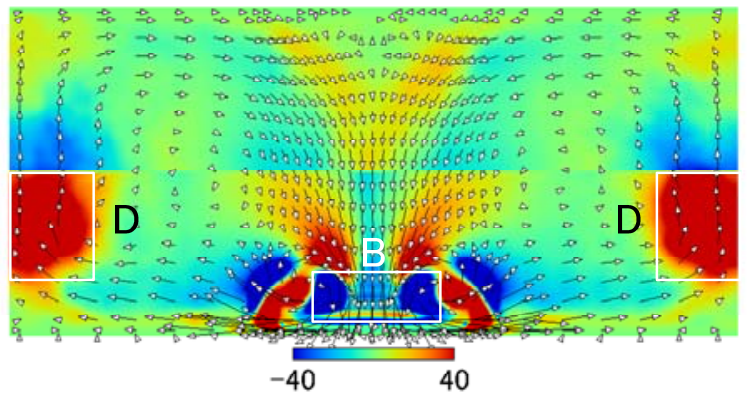

(a) Reynolds stress

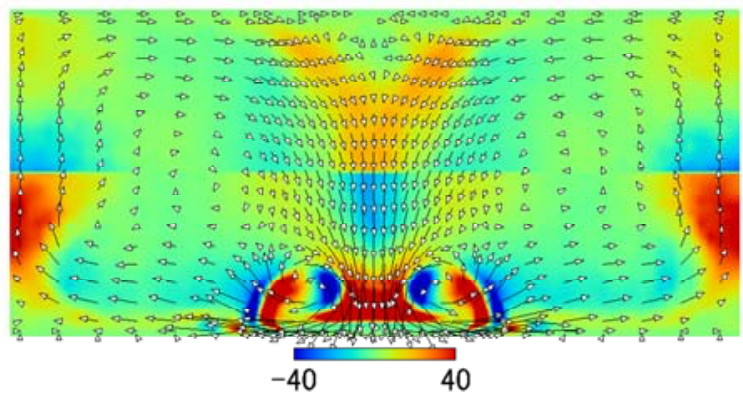

(b) Turbulent heat transfer

Fig. 15 Reynolds stress and turbulent heat transfer distributions in the channel with solid wall

その渦から発生した下流域の縦渦はなかなか減衰せず, 図 14 には一つ前の流路からの縦渦がまだ残っているのが わかる(図中の D). 強い縦渦により, 低速の流体が中心方向に押し上げられる結果, レイノルズ応力に正の寄与 を与える. 孔なし流路において, 図 14(b)の翼根元断面内でのレイノルズ応力の平均值と乱れ熱流束の平均值にそ れほど大きな差が見られないのは，この渦の効果による.

図 16 に，翼より下流 $x / L_{x}=0.70$ における孔なし流路における速度乱れの分布を示寸．同じ位置における孔あり の図 10(b)よりも，翼根元から発生する渦がかなり強いことがわかる. 負の速度乱れをもって巻き上がる渦は, レ イノルズ応力を顕著に押し上げる効果がある。 すなわち，孔なし流路で発生する強い縦渦が乱れ熱流束よりもレ イノルズ応力を顕著に励起するため，効率は悪化するといえる．本研究で扱った渦発生体において，効率は孔あ りの方が良好となる.

\section{5. 結言}

平行二平板間流れの層流および乱流中にデルタ翼状の渦発生体を取り付けた場合を対象に，プラントル数の効 率(伝熱促進率/圧力損失増加率)に及ぼす影響について, 直接数值計算結果から検討を行った. 圧力損失増加率, 伝熱促進率への寄与を整理する評価式を用い，様々な条件下における効率の挙動を数值計算結果に基づいて考察 を行った. 主な結果を以下に述べる.

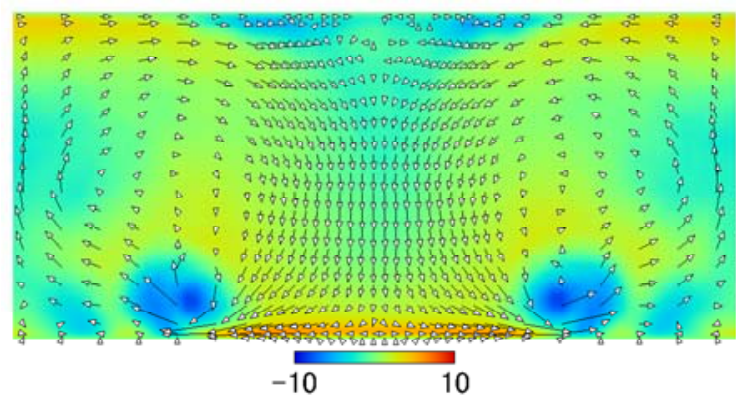

Fig.16 Fluctuation of stream wise velocity at $x / L_{x}=0.70$ (Solid wall, $\mathrm{Re}=9000$ ) 
層流中においては，もともと乱れがない状態に渦発生体を取り付けるため，渦発生体からの乱れが直接伝熱促 進率の増加に寄与寸る. プラントル数が大きくなるほど熱拡散が小さく乱れの抑制効果が小さくなることから, 乱れ熱流束の伝熱促進率への寄与はプラントル数の上昇に対して単調に増加する.プラントル数が大きくなると, 滑面流路からの平均温度分布の平坦化の度合いが顕著となり，壁面近傍の対流熱流束が大きくなる．これら二つ の要因により, 層流ではプラントル数が上昇すると効率が上昇し, $\mathrm{Re}=500$ では $\mathrm{Pr} \geqq 2, \mathrm{Re}=2000$ では $\mathrm{Pr} \geqq 1$ で $\eta>1$ の結果を与える.

乱流中に渦発生体を取り付けたとき，効率ならびに伝熱促進率はプラントル数の上昇に対してわずかに減少す る傾向を示した．プラントル数が小さいとき，滑面流路の乱れは抑制されるが，渦発生体により強制的に与えら れる大きな乱れはプラントル数にあまり依存しない，その結果，滑面流路に対する渦発生体流路の乱れ熱流束の 比は, プラントル数の上昇に対して若干減少する傾向を示寸. また, 平均温度分布の変化はプラントル数が大き くなると小さくなるため, 対流熱流束の効果も減少する. これら二つの要因により, 効率はプラントル数の上昇 に対して減少する.

$P r=1$ における層流 $R e=2000$ と乱流 $\mathrm{Re}=9000$ において, レイノルズ応力の圧力損失増加率への寄与はそれぞ れ同程度だが，乱れ熱流束の伝熱促進率の寄与は層流の方が大きくなった．この原因について，レイノルズ応力 と乱れ熱流束の流れ方向分布から考察を行った. 翼の後方で発生する縦渦内には低速の流体が存在し, 翼先端で はく離した強い下向き流れが吹き付けている. その結果, レイノルズ応力に強い負の寄与を与える. 一方, スカ ラー量である温度乱れは正の值を取るため, 乱れ熱流束がレイノルズ応力を卓越する強い非相似性が認められた. 翼の下流域において, 乱流の場合, 発生した縦渦が上向きの誘導速度を持つ結果, レイノルズ応力に正の寄与を 与える. 以上のことより, 層流では平均として乱れ熱流束が卓越し, 乱流では両者はほぼ等しくなる.ここで扱 った渦発生体から発生する乱れは，層流に対して伝熱促進により有効な効果を与える.

渦発生体を設置したときに生じる切り欠き孔の有無が, 効率に及ぼす影響について検討した. 数值計算の結果, 効率は孔がある方が有利で，伝熱促進率は孔のない方が有利となった，孔のある流路においては，翼に向かう近 寄り流れの一部が孔から流出するため, 発生する乱れが弱められる結果, 伝熱促進率が悪化する. 翼により発生 する縦渦の強度は，孔なし流路の方が大きい．上述した渦中の負の速度乱れが，強い縦渦により誘起された速度 により流路中心方向に輸送される. その結果, 孔のある場合よりもレイノルズ応力が強化される. 以上のことよ り, 乱れ熱流束よりもレイノルズ応力が卓越するため, 孔なし流路の効率は悪化する.

\section{文献}

(1) Webb, R.L., "Advances in modeling of enhanced heat transfer surfaces", Proceedings of the Tenth International Heat Transfer Conference, Vol. 1 (1994), pp. 445-460

(2) Bergles, A. E., "Heat Transfer Enhancement-The Encouragement and Accommodation of High Heat Fluxes", Transactions of the ASME, Journal of heat transfer, Vol. 119, No.1 (1997), pp. 8-19.

(3) Siddique, M., Khaled, A.-R. A., Abdulhafiz, I., and Boukhary, A.Y., "Recent Advances in Heat Transfer Enhancements: A review report", International Journal of Chemical Engineering, Vol. 2010 (2010), Article ID 106461, 28 pages.

(4) Webb, R. L., "Single-phase heat transfer, friction, and fouling characteristics of three-dimensional cone roughness in tube flow", International Journal of Heat and Mass Transfer, Vol. 52, No.11-12 (2009), pp. 2624-2631.

(5) Lawson, M. J. and Thole, K. A., "Heat transfer augmentation along the tube wall of a louvered fin heat exchanger using practical delta winglets", International Journal of Heat and Mass Transfer, Vol. 51, No.9-10 (2008), pp. 2346-2360.

(6) Eiamsa-ard, S., Wongcharee, K., Eiamsa-ard, P. and Thianpong, C., "Heat transfer enhancement in a tube using delta-winglet twisted tape inserts", Applied Thermal Engineering, Vol. 30, No.4 (2010), pp. 310-318.

(7) Joardar, A. and Jacobi, A. M., "A numerical study of flow and heat transfer enhancement using an array of delta-winglet vortex generators in a fin- and - tube heat exchanger", Transactions of the ASME, Journal of Heat Transfer, Vol. 129, No. 9 (2007), pp.1156-1167.

(8) Joardar, A. and Jacobi, A. M., "Heat transfer enhancement by winglet-type vortex generator arrays in compact plain-fin-and-tube heat exchangers”, International Journal of Refrigeration, Vol. 31, No. 1 (2008), pp. 87-97. 
(9) Sahu, A. K., Chhabra, R. P. and Eswaran, V., "Effects of Reynolds and Prandtl numbers on heat transfer from a square cylinder in the unsteady flow regime", International Journal of Heat and Mass Transfer, Vol. 52, No. 3-4 (2009), pp. 839-850.

(10) Meis, M., Varas, F., Velázquez, A. and Vega, J. M. "Heat transfer enhancement in micro-channels caused by vortex promoters", International Journal of Heat and Mass Transfer, Vol. 53, No. 1-3 (2010), pp. 29-40.

(11) García, A. Vicente, P. G. and Viedma, A., "Experimental study of heat transfer enhancement with wire coil inserts in laminar-transition-turbulent regimes at different Prandtl numbers", International Journal of Heat and Mass Transfer, Vol. 48, No. 21-22 (2005), pp. 4640-4651.

(12) Fiebig, M., "Embedded vortices in internal flow: heat transfer and pressure loss enhancement", International Journal of Heat and Fluid Flow, Vol. 16, No. 5 (1995), pp. 376-388.

(13) Jacobi, A. M. and Shah, R. K., "Heat transfer surface enhancement through the use of longitudinal vortices: A review of recent progress", Experimental Thermal and Fluid Science, Vol. 11, No. 3 (1995), pp. 295-309.

(14) Wu, J.M. and Tao, W. Q., "Numerical study on laminar convection heat transfer in a rectangular channel with longitudinal vortex generator. Part B: Parametric study of major influence factors", International Journal of Heat and Mass Transfer, Vol. 51, No. 13-14 (2008), pp. 3683-3692.

(15) Min, C., Qi, C., Kong, X. and Dong, J., "Experimental study of rectangular channel with modified rectangular longitudinal vortex generators", International Journal of Heat and Mass Transfer, Vol. 53, No. 15-16 (2010), pp. 3023-3029.

(16) Kaci, H. M., Habchi, C., Lemenand, T., Valle, D. D. and Peerhossaini, H., "Flow structure and heat transfer induced by embedded vorticity", International Journal of Heat and Mass Transfer, Vol. 53, No. 17-18 (2010), pp. 3575-3584.

(17) Chen, Y., Fiebig, M. and Mitra, N. K., "Heat transfer enhancement of finned oval tubes with staggered punched longitudinal vortex generators", International Journal of Heat and Mass Transfer, Vol. 43, No. 3 (2000), pp. 417-435.

(18) O’Brien, J. E., Sohal, M. S. and Wallstedt, P. C., "Local heat transfer and pressure drop for finned-tube heat exchangers using oval tubes and vortex generators", Transactions of the ASME, Journal of Heat Transfer, Vol. 126, No. 5 (2004), pp. 826-835.

(19) Zhang, Y-H., Wu, X., Wang, L-B., Song, K-W., Dong, Y-X. and Liu, S., "Comparison of heat transfer performance of tube bank fin with mounted vortex generators to tube bank fin with punched vortex generators", Experimental Thermal and Fluid Science, Vol. 33, No. 1 (2008), pp. 58-66.

(20) Wu, J.M. and Tao, W. Q., "Numerical study on laminar convection heat transfer in a rectangular channel with longitudinal vortex generator. Part A: Verification of field synergy principle”, International Journal of Heat and Mass Transfer, Vol. 51, No. 5-6 (2008), pp. 1179-1191.

(21) Katoh, K., Choi, K-S. and Azuma, T., "Heat-transfer enhancement and pressure loss by surface roughness in turbulent channel flows", International Journal of Heat and Mass Transfer, Vol. 43, No. 21 (2000), pp. 4009-4017.

(22) 加藤健司, 東恒雄, “渦発生体付き流路における圧力損失と伝熱促進の関係について”, 日本機械学会論文集 B編, Vol. 69, No.685 (2003), pp. 2091-2098

(23) Fiebig, M., Kallweit, P., Mitra, N. and Tiggelbeck, S., "Heat transfer enhancement and Drag by Longitudinal Vortex Generators in Channel Flow”, Experimental Thermal and Fluid Science, Vol. 4, No. 1 (1991), pp. 103-114.

(24) Young, T. J. and Vafai, K., "Convective flow and heat transfer in a channel containing multiple heated obstacles", International Journal of Heat and Mass Transfer, Vol. 41, No. 21 (1998), pp. 3279-3298.

(25) 梶島岳夫, 乱流の数值シミュレーション, 第 4 版 (2010), p. 144, 養賢堂.

(26) Sahu, A. K., Chhabra, R. P. and Eswaran, V., "Effects of Reynolds and Prandtl numbers on heat transfer from a square cylinder in the unsteady flow regime", International Journal of Heat and Mass Transfer, Vol. 52, No. 3-4 (2009), pp. 839-850.

(27) Iwamoto, K., Suzuki, Y. and Kasagi, N., "Database of fully developed channel flow", THTLAB Internal Report, No. ILR-0201, (2002), Department of Mechanical Engineering, The University of Tokyo.

(28) Kays, W. M. and Crawford, M. E., Convective Heat and Mass Transfer, Second Edition (1980), p. 236, McGraw-Hill. 